\title{
ANIMAL TOXINS: STATE OF THE ART - PERSPECTIVES IN HEALTH AND BIOTECHNOLOGY
}

\section{Organizers: Maria Elena de Lima, Adriano Monteiro de Castro Pimenta, Marie France Martin-Eauclaire, Russolina Benedeta Zingali and Hervé Rochat.}

Editora UFMG, 2009, 800 p., ISBN: 978-85-7041-735-0.

This single-volume edition presents for the first time results of several studies with different perspectives on the real possibilities of the use of animal venoms and toxins in the biotechnology industry.

Animal Toxins consists of 39 articles, signed by renowned experts of various nationalities. The state of the art in compounds derived from venoms of marine animals, spiders and scorpions, lizards, snakes, among others, are the focus of this publication which aims to meet scientists, students and university researchers, biotechnologists interested in toxicology as well as the pharmaceutical industry.

Animal venoms and toxins have been selected over millions of years of evolution to act quickly and effectively on the victim body, which results in a massive repertoire of molecules able to bind to specific targets. The possibility of using these toxins in biotechnological processes means that these venoms and toxins are regarded as one of the most promising sources of bioactive natural compounds.

FINANCIAL SOURCE: Fapemig, Fundep, INCTT (Instituto Nacional de Ciência e Tecnologia em Toxinas).

\section{CORRESPONDENCE TO:}

MARIA ELENA DE LIMA, Laboratório de Venenos e Toxinas Animais, Departamento de Bioquímica e Imunologia, Instituto de Ciências Biológicas, Universidade Federal de Minas Gerais, Av. Antônio Carlos, 6627, Belo Horizonte, MG, 30171-970, Brasil. Phone: +55 313409 2659. Fax: +55 313409 2614. Email: melenalima@icb.ufmg.br. 
Lima ME et al. Animal toxins: State of the Art - Perspectives in health and biotechnology. J Venom Anim Toxins incl Trop Dis. 2009;15(3):586

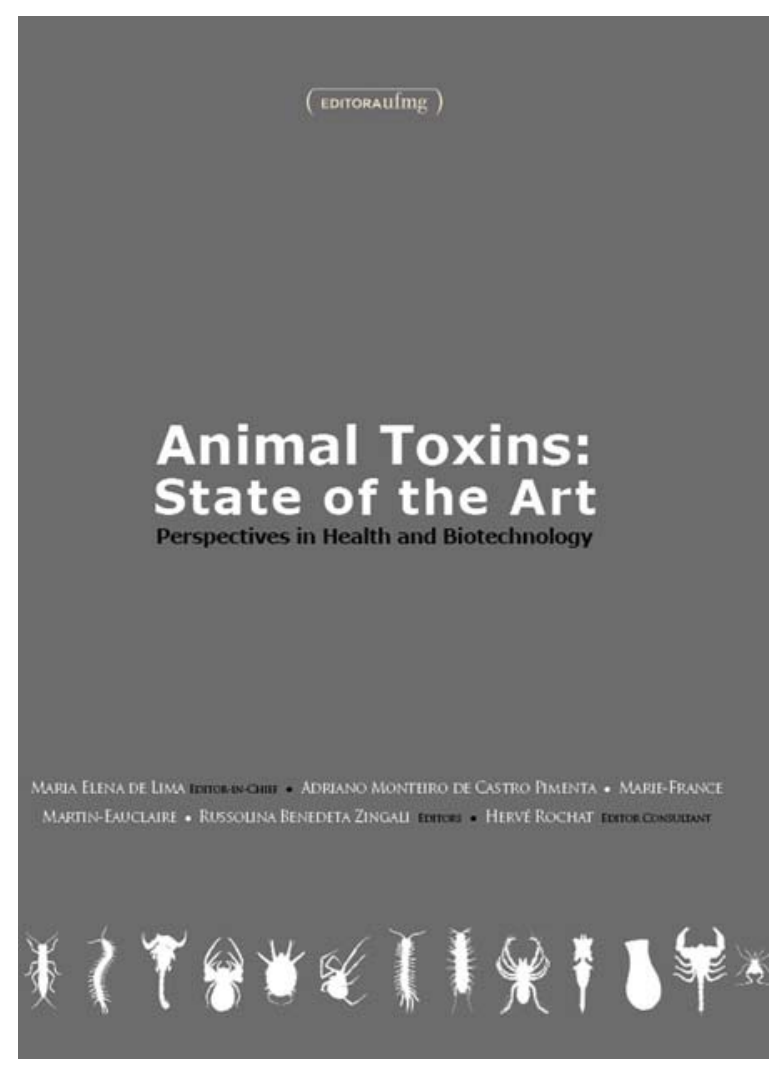

